\title{
Altitudinal zonality and natural zoning as factors of bottom invertebrate communities formation in lakes of Western Siberia and Russian Altai
}

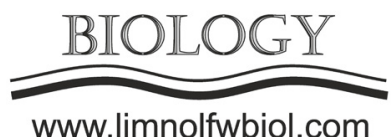

\author{
Bezmaternykh D.M.*, Vdovina O.N. \\ Institute for Water and Environmental Problems, Siberian Branch of the Russian Academy of Sciences, 1, Molodezhnaya St., 656038 \\ Barnaul, Altai Krai, Russia

\begin{abstract}
In 2003-2016 and 2018, macrozoobenthos from 60 lakes of Western Siberia and the Russian Altai was studied. The lakes refer to high- and medium-altitudinal zones as well as steppe, forest-steppe and taiga natural zones. In lakes under study, we identified 183 species of macroinvertebrates from 10 classes: Demospongiae (1 species), Nematoda (1), Oligochaeta (7), Hirudinea (5), Phylactolemata (1), Bivalvia (4), Gastropoda (10), Arachnida (1), Crustacea (2) and Insecta (151). Species number, species diversity, abundance and biomass of macrozoobenthos in high-altitudinal and natural zones differed both in their average values and within individual zones and belts. Among major factors responsible for benthic communities development in the mountain lakes were water temperature and nutrients content in water, whereas in the lowland water bodies - salinity and humification of water.
\end{abstract}

Keywords: zoobenthos, lakes, natural zoning, altitude, environmental factors

\section{Introduction}

Being the accumulating element of landscapes, lake ecosystems largely depend on climate-induced soil and geochemical processes occurred in the basin (Rossolimo, 1964). Since the zonal features of the area reflect the total impact of various but interrelated environmental factors (Milkov, 1986), it is expedient to consider macrozoobenthos distribution in relation to natural zoning and altitudinal zonality of lake catchments. The purpose of this work is to study the composition and structure of bottom invertebrate communities in lakes from various natural zones of Western Siberia and altitudinal belts of Altai.

\section{Materials and methods}

In the course of complex limnological investigations of 2003-2016 and 2018, we studied zoobenthos of Western Siberia lakes located in three natural zones (forest-steppe, steppe and taiga with its studied sub-taiga subzone) as well as high- and middlemountain lakes of the Russian Altai. A total of 60 lakes was studied, 425 quantitative and 96 qualitative benthic samples were taken and analyzed. The material for research was sampled and processed using the standard methods (Abakumov et al., 1992). The studied lakes are located in three natural zones (steppe, foreststeppe, taiga) and in two high-altitudinal zones (mid- and high-mountains). A detailed description of these lakes is given in our previous works (Bezmaternykh and Vdovina, 2020; Vdovina and Bezmaternykh, 2020).

\section{Results and discussion}

In the lakes of Western Siberia and the Russian Altai, 183 species of macroinvertebrates from 10 classes were identified: Demospongiae (1 species), Nematoda (1), Oligochaeta (7), Hirudinea (5), Phylactolemata (1), Bivalvia (4), Gastropoda (10), Arachnida (1), Crustacea (2), Insecta (151). Diptera (84 species, 51 of which are chironomids) was the most diverse among insects. We also identified dragonflies (12), collembolan insects (1), mayflies (5), bedbugs (12), butterflies (2), caddis flies (16), beetles (18), and large-winged insects (1).

Lakes of high and mid mountain zones did not differ greatly in zoobenthos development and taxonomic structure. The least species number of bottom invertebrates (6.2 per lake) was observed in high-altitudinal lakes distinguished by insignificant spread in value for different reservoirs (1-14). For macrozoobenthos biomass in mid mountain lakes, this index was the least $\left(0.002-3.96 \mathrm{~g} / \mathrm{m}^{2}\right)$ as compared to the average (1.2).

In contrast to mountain lakes, the lowland ones showed higher average values of species number, species diversity and macrozoobenthos biomass. For different lakes, spread in value for these indicators 
was significant. Species diversity of macrozoobenthos from lakes in the steppe zone was slightly higher (1.17 bps) on the average than that of mountain water bodies (0.86-0.94). The forest-steppe zone showed the largest variation in species number (2-28), species diversity (0.5-3 bits/ex.), population (0.5-21 th. indiv. $/ \mathrm{m}^{2}$ ) and benthic biomass (0.83-40). At the same time, average values of the mentioned indicators in this zone were higher than in others. The average number of macrozoobenthos in taiga lakes and spread of this indicator $\left(0.78\right.$ th. indiv. $/ \mathrm{m}^{2}$ and $0.14-2.02$, respectively) were the lowest.

Major negative factors responsible for the bottom community development in the mountain lakes are low water temperature and insufficient nutrients amount in water. In the steppe and forest-steppe zones, the limiting factor for their development is generally high water salinity, whereas in the sub-taiga zone the emerging increased water humification (Vdovina and Bezmaternykh, 2019). The impact of local environmental factors associated with specific lakes' features (e.g. soil type, depth, chemical composition of water, macrophyte overgrowth, etc.) should be taken in consideration as well (Bezmaternykh and Zhukova, 2013).

The results obtained are in agreement with the data from early studies. Previous research report that high-altitudinal lakes located within the subalpine zones are almost completely lifeless. With descending from mountain peaks, the fauna starts to resemble that of lowland lakes. It is worthy of note that low water temperature and trophic state hamper hydrobionts development in mountain lakes (Zhadin and Gerd, 1961).

\section{Acknowledgments}

We sincerely thank staff members at the Laboratory of Aquatic Ecology and Center of Aquatic Expedition Research of the Institute for Water and
Environmental Problems, Siberian Branch, Russian Academy of Sciences, Barnaul, Russia, for assistance in sampling and processing materials. This study was carried out as part of State Task (registration no. AAAA-A17-117041210244-5).

\section{References}

Bezmaternykh D.M., Vdovina O.N. 2020. Composition and structure of macrozoobenthos of lakes in different natural zones and subzones of Western Siberia. Limnology 21: 3-13. DOI: $10.1007 / \mathrm{s} 10201-019-00586-y$

Bezmaternykh D.M., Zhukova O.N. 2013. Composition, structure and factors of benthic invertebrate communities formation in lakes of the south of the Ob-Irtysh interfluve. Russian Journal of Ecology 44: 170-177. DOI: 10.1134/ S1067413613020057

Milkov F.N. 1986. Fizicheskaya geografiya: ucheniye o landshafte i geograficheskaya zonal'nost' [Physical geography: landscape studies and geographical zonality]. Voronezh: Izdatel'stvo Voronezhskogo universiteta. (in Russian)

Rossolimo L.L. 1964. Fundamentals of lake typification and limnological zoning. In: Nakopleniye veshchestva $\mathrm{v}$ ozerakh [Accumulation of matter in lakes]. Moscow, pp. 5-46. (in Russian)

Abakumov V.A., Tal'skikh V.N., Popchenko V.I. et al. 1992. Rukovodstvo po gidrobiologicheskomu monitoringu presnovodnykh ekosistem [Manual on hydrobiological monitoring of freshwater ecosystems]. St.-Petersburg: Gidrometeoizdat. (in Russian)

VdovinaO.N., Bezmaternykh D.M. 2019. Macrozoobenthos composition and structure in Lakes of the sub-taiga sub-zone of Western Siberia. Hydrobiological Journal 55: 103-107. DOI: 10.1615/HydrobJ.v55.i3.120

Vdovina O.N., Bezmaternykh D.M. 2020. Communities of bottom macroinvertebrates of high- and mid- altitudinal mountain lakes of the Russian Altai. Rybovodstvo i Rybnoye Khozyaystvo [Fish Farming and Fisheries] 2: 4-13. (in Russian)

Zhadin V.I., Gerd S.V. 1961. Reki, ozera i vodokhranilishcha SSSR, ikh fauna i flora [Rivers, lakes and reservoirs of the USSR, their fauna and flora]. Moscow: Gosudarstvennoye uchebno-pedagogicheskoye izdatel'stvo Ministerstva Prosveshcheniya RSFSR. (in Russian) 